ISSN 0258-7122

Bangladesh J. Agril. Res. 38(1): 49-59, March 2013

\title{
RESPONSE OF CHILLI (Capsium annuum L.) TO ZINC AND BORON APPLICATION
}

\author{
N. C. SHIL ${ }^{1}$, H. M. NASER ${ }^{2}$, S. BRAHMA ${ }^{2}$ \\ M. N. YOUSUF ${ }^{3}$ AND M. H. RASHID ${ }^{2}$
}

\begin{abstract}
Field trial on chilli (cv. Bogra local) was conducted in Grey Terrace Soil under AEZ-25 (Level Barind Tract) at Spice Research Centre, Bogra during rabi seasons of 2005-2006, 2006-2007 and 2007-2008. The objectives were to evaluate the response of chilli to zinc and boron and to find out the optimum dose of zinc and boron for maximizing the yield. Treatments for this study comprised of four levels each of zinc $(0,1.5,3.0$, and $4.5 \mathrm{~kg} / \mathrm{ha})$ and boron $(0$, 1.0, 2.0, and $3.0 \mathrm{~kg} / \mathrm{ha}$ ) along with a blanket dose of $\mathrm{N}_{130} \mathrm{P}_{60} \mathrm{~K}_{80} \mathrm{~S}_{20} \mathrm{Mg}_{10} \mathrm{~kg} / \mathrm{ha}$. The experiment was set up in a randomized block design (factorial) with 3 replications. The integrated use of zinc and boron was found superior to their single applications. The interaction effect between zinc and boron was significant in case of yield of dry chilli and weight of ripe chilli/plant. The highest yield (1138 kg/ha) was recorded from $\mathrm{Zn}_{3} \mathrm{~B}_{1} \mathrm{~kg} / \mathrm{ha}$, which was closely followed by $\mathrm{Zn}_{3} \mathrm{~B}_{2}, \mathrm{Zn}_{4.5} \mathrm{~B}_{2}$ and the lowest (703 kg/ha) in control $\left(\mathrm{Zn}_{0} \mathrm{~B}_{0}\right)$. The yield benefit over control varied from 4.4 to $61.9 \%$ due to interaction effect. Consecutive three years studies showed almost similar trend of results. However, from regression analysis, the optimum-economic dose of zinc was found to be $3.91 \mathrm{~kg} / \mathrm{ha}$ whereas it was 1.70 for boron. Hence, a package of $\left(\mathrm{Zn}_{3.91} \mathrm{~B}_{1.70} \mathrm{~kg} / \mathrm{ha}\right)$ along with the said blanket dose may be recommended for maximizing the yield of chilli in the study area.
\end{abstract}

Keywords: Chilli, zinc, boron, optimum yield.

\section{Introduction}

Chilli (Capsium annuum L.), the most important spice crop is grown all over Bangladesh. It is an indispensable spice, which is liked for pungency and spicy taste and the appealing colour adds to the curry. Chilli occupies about 1,80,000 hectares with a production of 1,50,000 tons (BBS, 2001). However, the average yield of dry chilli is low (700-800 kg/ha) in Bangladesh compared to the neighbouring countries (1000-1200 kg/ha). One of the reasons of lower yield might be imbalanced use of fertilizers and manure and low levels of available $\mathrm{Zn}$ and B in the soils of major chilli growing areas. It is realized that productivity of crop is being adversely affected in different areas due to deficiencies of

\footnotetext{
${ }^{1}$ Principal Scicentific Officer, Soil Science Division, Bangladesh Agricultural Research Institute (BARI), Gazipur, ${ }^{2}$ Senior Scientific Officer, Spice Research Center, BARI, Bogra, ${ }^{3}$ Scientific Officer, Spice Research Sub-Center, Bogra, ${ }^{4}$ Scientifc Officer, Soil Science Division, BARI, Gazipur, Bangladesh.
} 
micronutrients (Bose and Tripathi, 1996). The deficiency of micronutrients increased markedly due to intensive cropping, loss of top soil by erosion, loss of micronutrients by leaching, liming of soil and lower availability and use of farm yard manure (Fageria et al., 2002). Micronutrients are usually required in minute quantities, nevertheless are vital to the growth of plant (Benepal, 1967). Improvement in growth characters as a result of application of micronutrients might be due to the enhanced photosynthetic and other metabolic activity which leads to an increase in various plant metabolites responsible for cell division and elongation as opined by Hatwar et al. (2003). The photosynthesis enhanced in presence of zinc and boron was also reported by Rawat and Mathpal (1984). Mallick and Muthukrishnan (1979) explained that presence of zinc activates the synthesis of tryptophan, the precursor of IAA and it is responsible for stimulated plant growth. The deficiency of B retards apical growth and development because of its impacts on cell development and on sugar formation and translocation. Boron also plays an important part in flowering and fruiting processes, $\mathrm{N}$ metabolism, hormonal action and cell division.

The nutrient removal and uptake capacity by capsicum cultivar is higher, which indicates the greater nutrient requirements by chilli. Integrated use of both chemical fertilizers and organic manure was found significant in increasing the growth and yield of chilli (Sharma et al., 1996; and Hegde, 1997). Nitrogen @ 120 kg/ha and P @ 60 kg/ha produced significantly higher yield of chilli (Sharma et al., 1996). Singh and Srivastava (1998) recommended $120 \mathrm{~kg} \mathrm{~N}$ and $60 \mathrm{~kg}$ P/ha for high yield. Karnataka (2009) recorded highest yield of chilli with N P K @ 100:50:50 kg/ha and secondary and micronutrients. Ahmed and Tanki (1991) worked out the optimum dose of nitrogen and phosphorus to be $120 \mathrm{~kg} / \mathrm{ha}$ and $82.8 \mathrm{~kg} / \mathrm{ha}$, respectively. Potassium had no influence on yield, duration of flowering, plant height, and fruit ripening. Sporadic research works on nutrient management on chilli were done where $\mathrm{N}, \mathrm{P}, \mathrm{K}$, and $\mathrm{S}$ fertilizers were considered for recommendation. However, no systematic research work has been done so for to find out the response of chilli to zinc and boron fertilization.

The potential chilli growing soils in north-western regions of Bangladesh was reported to be zinc and boron deficient. Like many other crops, chilli might be responsive to zinc and boron fertilization especially for rabi season when the availability of $\mathrm{Zn}$ is likely to reduce further due to low temperature. The present study was therefore, undertaken (i) to evaluate the response of zinc and boron on chilli and (ii) to find out the optimum dose of zinc and boron for maximizing the yield of chilli.

\section{Materials and Method}

The experiment was conducted in Grey Terrace Soil under AEZ-25 (Level Barind Tract) at Spices Research Centre (SRC), Bogra during rabi seasons of 
2005-2006, 2006-2007 and 2007-2008. The initial soil samples of the experiment field were collected and analyzed following standard laboratory procedures and are presented in Table 1. The soil was slightly acidic ( $\mathrm{pH}$ 6.2) having low organic matter content (1.12 \%). The content of total-N was very low. The exchangeable $\mathrm{K}$ and $\mathrm{Mg}$ contents were low. Available $\mathrm{P}$ and $\mathrm{S}$ contents were also low. In particular, the contents of available $\mathrm{Zn}$ and $\mathrm{B}$ were low too. There were 16 treatment combinations comprising 4 levels each of boron (0, 1, 2 and $3 \mathrm{~kg} / \mathrm{ha}$ ) and zinc (0, 1.5, 3.0 and $4.5 \mathrm{~kg} / \mathrm{ha}$ ). Besides, a blanket dose of $\mathrm{N}_{130} \mathrm{P}_{60} \mathrm{~K}_{80} \mathrm{~S}_{20}$ $\mathrm{Mg}_{10} \mathrm{~kg} / \mathrm{ha}$ was used in the study. The treatments were arranged in a randomized block design (factorial) with 3 replications. The size of the unit plot was $3 \mathrm{~m} \mathrm{x}$ $2.4 \mathrm{~m}$. All fertilizers except $\mathrm{N}$ were applied at the time of final land preparation. Nitrogen was top dressed in 4 equal splits at 5, 30, 55 and 75 days after planting followed by light irrigation. Zinc and boron were applied as zinc sulphate and boric acid, respectively. About one month old seedlings of chilli (cv. Bogra local) were transplanted on the last week of December maintaining a spacing of row to row $40 \mathrm{~cm}$ and plant to plant $30 \mathrm{~cm}$. Intercultural operations and plant protection measures were done to keep the plant healthy. Ripe fruits of chilli were harvested and sun dried during May. Crop performance data on plant height, fruit length, fruit breadth and yield were recorded and statistically analyzed using MSTATC Package.

Table 1. Fertility status of initial soil sample of the experimental field at SRC, Bogra.

\begin{tabular}{|c|c|c|c|c|c|c|c|c|c|c|c|}
\hline \multirow[b]{2}{*}{ Item } & \multirow[b]{2}{*}{$\mathrm{pH}$} & \multirow{2}{*}{$\begin{array}{l}\text { OM } \\
(\%)\end{array}$} & \multirow{2}{*}{$\begin{array}{c}\text { Total } \\
\mathrm{N} \\
(\%) \\
\end{array}$} & $\mathrm{Ca}$ & $\mathrm{Mg}$ & $\mathrm{K}$ & $\mathrm{P}$ & $\mathrm{S}$ & $\mathrm{Mn}$ & $\mathrm{Zn}$ & $\mathrm{B}$ \\
\hline & & & & \multicolumn{3}{|c|}{ meq $100 \mathrm{~g}^{-1}$} & \multicolumn{5}{|c|}{$\mu \mathrm{g} \mathrm{g}^{-1}$} \\
\hline Result & 6.2 & 1.12 & 0.06 & 3.6 & 0.7 & 0.18 & 12 & 13 & 5 & 1.1 & 0.16 \\
\hline $\begin{array}{l}\text { Critical } \\
\text { level }\end{array}$ & - & - & 0.12 & 2.0 & 0.8 & 0.2 & 14 & 14 & 5 & 2 & 0.20 \\
\hline $\begin{array}{l}\text { Interpre- } \\
\text { tation }\end{array}$ & $\begin{array}{l}\text { Slightly } \\
\text { Acidic }\end{array}$ & Low & $\begin{array}{l}\text { Very } \\
\text { low }\end{array}$ & $\begin{array}{l}\text { Opti- } \\
\text { mum }\end{array}$ & Low & Low & Low & Low & At par & Low & Low \\
\hline
\end{tabular}

\section{Results and Discussion Interaction effect}

Yield component: The yield components like plant height, length and breadth of fruit did not alter significantly due to interaction ( $\mathrm{Zn} \times \mathrm{B}$ ) effect although combined application of both the elements augmented higher results than their single application, which collectively might have contributed to the yield (Table 2). 
Table 2. Interaction effect of boron and zinc on the yield component of chilli at SRC Bogra.

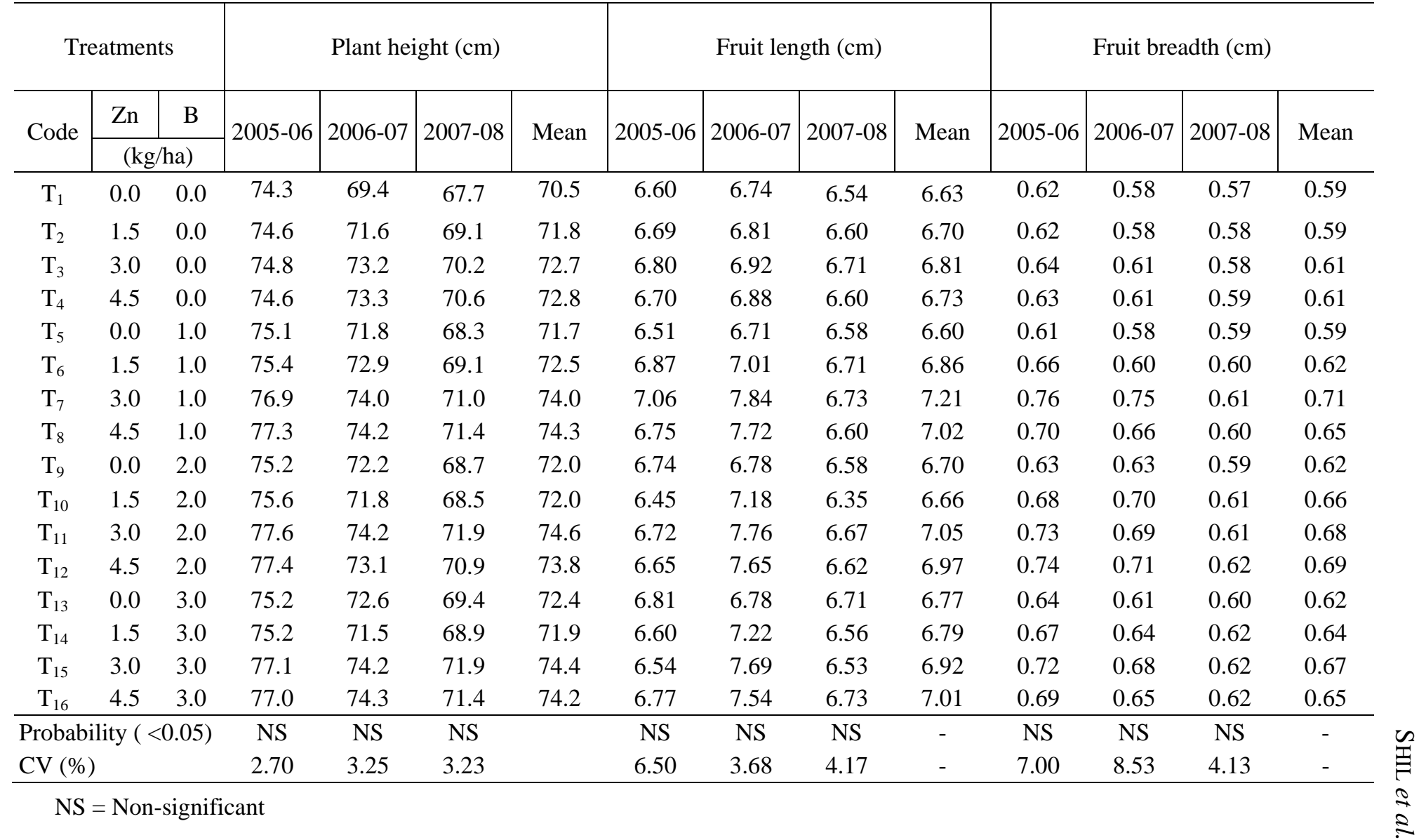


Table 3. Interaction effect of boron and zinc on yield of chilli at SRC, Bogra.

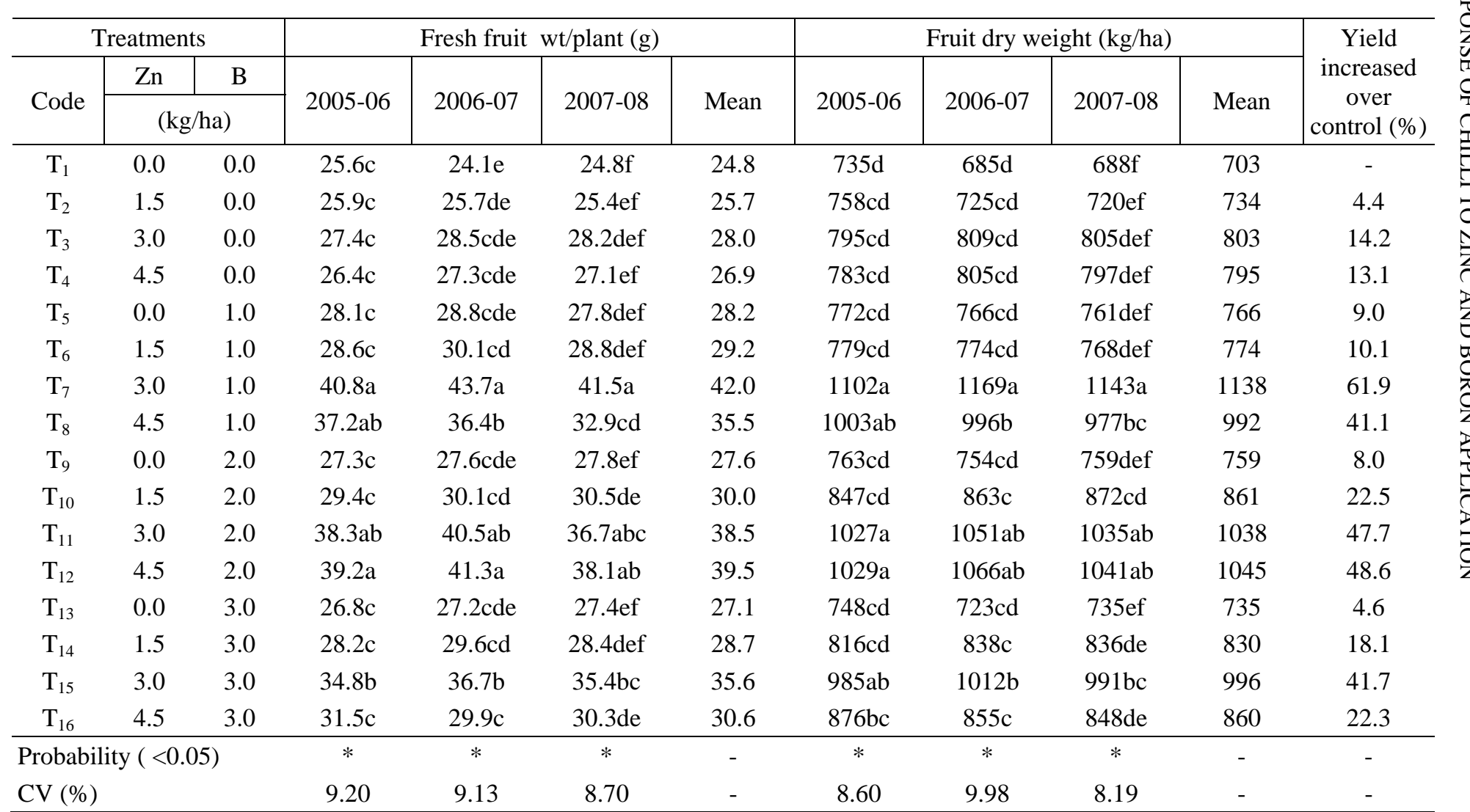

Figures in a column having same letter(s) do not differ significantly at 5 percent level by DMRT 
The mean plant height varied from $70.5 \mathrm{~cm}$ to $74.6 \mathrm{~cm}$ where the highest result was observed in $\left(\mathrm{Zn}_{3} \mathrm{~B}_{2}\right)$ followed by $\mathrm{Zn}_{4.5} \mathrm{~B}_{1}$ and the lowest in control $\left(Z_{0} B_{0}\right)$. The highest fruit length $(7.21 \mathrm{~cm})$ was found in $Z_{3} B_{1}$ followed by $\mathrm{Zn}_{3} \mathrm{~B}_{2}$ and the lowest in control. Again, the fruit breath due to interaction ranged from $0.59 \mathrm{~cm}$ to $0.71 \mathrm{~cm}$ where the highest result was observed in $\mathrm{Zn}_{3} \mathrm{~B}_{1}$ followed by $\mathrm{Zn}_{4.5} \mathrm{~B}_{2}$ and the lowest in control (Table 2).

\section{Yield}

The interaction effect between zinc and boron was found statistically significant for the yield of dry chilli (Table 3). The yield of ripe fruits/plant was found highest (40.8, 43.7 and 41.5g for the first, second and third year, respectively) in $\mathrm{T}_{7}\left(\mathrm{Zn}_{3} \mathrm{~B}_{1}\right)$, which was statistically identical with $\mathrm{T}_{11}\left(\mathrm{Zn}_{3} \mathrm{~B}_{2}\right)$ and $\mathrm{T}_{12}\left(\mathrm{Zn}_{4.5} \mathrm{~B}_{2}\right)$ but significantly higher over other combinations and single application of either zinc or boron. The mean yield of ripe fruits/plant varied from 24.8 to $42.0 \mathrm{~g}$ where the highest result was observed in $T_{7}$ followed by $T_{12}$ and $T_{11}$ and the lowest in $\mathrm{T}_{1}\left(\mathrm{Zn}_{0} \mathrm{~B}_{0}\right)$. However, combined application of both zinc and boron contributed higher fruit weight than their single application. The yield of dry chilli also increased significantly due to integrated use of both zinc and boron. The highest yield (1102, 1169 and $1143 \mathrm{~kg} / \mathrm{ha}$ for the first, second and third year, respectively) was recorded form $T_{7}\left(Z_{3} B_{1}\right)$, which was identically followed by $\mathrm{T}_{12} \quad\left(\mathrm{Zn}_{4.5} \mathrm{~B}_{2}\right)$ and $\mathrm{T}_{11} \quad\left(\mathrm{Zn}_{3} \mathrm{~B}_{2}\right)$, but significantly higher over remaining combinations and single application of either zinc or boron. The mean yield of dry chilli ranged from 703 to $1138 \mathrm{~kg} / \mathrm{ha}$ where the highest result was observed in $T_{7}$, which was followed by $T_{12}$ and $T_{11}$ and the lowest in control. However, the interaction effect became narrower when either lowest or highest dose of zinc applied with either lowest or highest dose of boron. These explanations can be well understood when yield increase (\%) over control by different treatments are compared (Table 3). Integrated use of $\mathrm{Zn}$ and B contributed 10.1 - $61.9 \%$ increased yield over control while single application contributed only 4.4 to $14.2 \%$ and 4.6 to $9.0 \%$ for zinc and boron, respectively, which signifies their requirement for optimizing the yield of chilli (Table 3). Hatwar et al. (2003) reported application of micronutrients viz., zinc, iron and boron in combination, which resulted in improvement of growth, yield parameters and yield of chilli. Consecutive three years studies provided almost similar trend of results. Thus, integrated use of boron and zinc are remunerative in augmenting the yield of chilli in the study area.

\section{Main effect of zinc}

Zinc played significant role in augmenting the yield components and yield of chilli (Table 4). The yield of dry chilli increased significantly due to added zinc. The highest yield (977, 1010 and $994 \mathrm{~kg} / \mathrm{ha}$ for the first, second and third year, respectively) was found with $3.0 \mathrm{~kg} \mathrm{Zn/ha,} \mathrm{which} \mathrm{was} \mathrm{significantly} \mathrm{higher} \mathrm{over}$ 
rest of the doses. The mean yield was $993.7 \mathrm{~kg} / \mathrm{ha}$, which was 33.9\% higher over zinc control. Lower dose of zinc (1.5 kg/ha) increased the yield only by $8.1 \%$ while the highest dose $(4.5 \mathrm{~kg} \mathrm{Zn} / \mathrm{ha})$ contributed $24.4 \%$ yield benefit over control (Table 4). These results are in conformity with the findings of Pillai (1967) and Pillai and Vadivelu (1966). Fresh fruit weight/plant was also varied significantly due to zinc as reveled by the three years' results. The highest fresh ripe fruit weight (35.5, 37.4 and $35.3 \mathrm{~g} /$ plant for the first, second and third year, respectively) was recorded from $3.0 \mathrm{~kg} \mathrm{Zn/ha,} \mathrm{which} \mathrm{was} \mathrm{significantly} \mathrm{higher}$ over rest of the doses for the second and third year. Incase of first year, it was identical with $4.5 \mathrm{~kg} \mathrm{Zn/ha} \mathrm{but} \mathrm{significantly} \mathrm{higher} \mathrm{over} \mathrm{rest} \mathrm{of} \mathrm{the} \mathrm{doses.} \mathrm{Yield}$ components like plant height, fruit length and breath were influenced markedly due to added zinc (Table 4).

\section{Main effect of Boron}

The main effect of boron on the yield and yield component of chilli are presented in Table 4. The highest dry yield (917, 933 and $933 \mathrm{~kg} / \mathrm{ha}$ for the first, second and third year, respectively) was obtained with $2.0 \mathrm{~kg} \mathrm{~B} / \mathrm{ha}$, which was significantly higher over control and the highest dose ( $3.0 \mathrm{~kg} \mathrm{~B} / \mathrm{ha}$ ) but at par with immediate lower dose (1.0 kg B/ha). Three years' mean yield varied from 759.0 to $927.7 \mathrm{~kg} /$ ha where the highest result was estimated with $2.0 \mathrm{~kg} \mathrm{~B} / \mathrm{ha}$ and the lowest in boron control. As a result, boron contributed yield benefit over control by 20.9, 22.2 and $13.0 \%$ for $1.0,2.0$ and $3.0 \mathrm{~kg} \mathrm{~B} / \mathrm{ha}$, respectively. These findings revealed that $1.0-2.0 \mathrm{~kg} \mathrm{~B} / \mathrm{ha}$ are sufficient enough for maximizing the yield of chilli. The yield of chilli was increased with boron application as reported by Govindan (1952)

The yield contributing characters like fruit breadth and weight of fresh ripe fruits/plant increased significantly due to boron but different boron doses produced identical results although slight variations were noticed (Table 4). Three years mean result showed that the fresh fruit weight varied from $26.4 \mathrm{~g}$ to $33.9 \mathrm{~g} / \mathrm{plant}$ where the highest value was found with $1.0 \mathrm{~kg} \mathrm{~B} / \mathrm{ha}$ followed by 2.0 $\mathrm{kg} \mathrm{B} / \mathrm{ha}$ and the lowest in B control. The plant height and fruit length did not alter significantly due to boron variation.

\section{Response function}

A quadratic relationship was observed between dry chilli yield and added zinc (Fig. 1). The optimum dose (3.96 kg/ha) of zinc was calculated from the quadratic equation (Table 5). Using the same optimum dose, the maximum yield (949 kg/ha) could be expected for chilli at Bogra. However, the economic dose $(3.91 \mathrm{~kg} / \mathrm{ha})$ of zinc was calculated from the quadratic response function. Besides, regression equation showed that, each $1 \mathrm{~kg} Z \mathrm{Zn}$ could produce $100 \mathrm{~kg} / \mathrm{ha}$ yield of dry chilli. Beyond the said optimum dose, if $1 \mathrm{~kg}$ excess $\mathrm{Zn}$ is applied then there is a risk of losing $14.5 \mathrm{~kg} / \mathrm{ha}$ of dry yield. 
Table 4. Main effect of zinc and boron on the yield attributes and yield of chilli at Bogra.

\begin{tabular}{|c|c|c|c|c|c|c|c|c|c|c|c|c|c|c|c|c|c|c|}
\hline \multirow[b]{2}{*}{ Treatment } & \multicolumn{3}{|c|}{ Plant height (cm) } & \multicolumn{3}{|c|}{ Fruit length (cm) } & \multicolumn{3}{|c|}{ Fruit breadth $(\mathrm{cm})$} & \multicolumn{4}{|c|}{$\begin{array}{l}\text { Fresh ripe fruit weight/ } \\
\text { plant (g) }\end{array}$} & \multicolumn{4}{|c|}{ Yield (kg/ha) } & \multirow{2}{*}{$\begin{array}{c}\text { Yield } \\
\text { increase } \\
\text { over } \\
\text { control } \\
(\%)\end{array}$} \\
\hline & $\begin{array}{l}2005- \\
06\end{array}$ & $\begin{array}{c}2006- \\
07\end{array}$ & $\begin{array}{c}2007- \\
08\end{array}$ & $\begin{array}{l}2005- \\
06\end{array}$ & $\begin{array}{c}2006- \\
07\end{array}$ & $\begin{array}{c}2007- \\
08\end{array}$ & $\begin{array}{l}2005- \\
06\end{array}$ & $\begin{array}{c}2006- \\
07\end{array}$ & $\begin{array}{c}2007- \\
08\end{array}$ & $\begin{array}{l}2005- \\
06\end{array}$ & $\begin{array}{c}2006- \\
07\end{array}$ & $\begin{array}{c}2007- \\
08\end{array}$ & Mean & $\begin{array}{l}2005- \\
06\end{array}$ & $\begin{array}{c}2006- \\
07\end{array}$ & $\begin{array}{c}2007- \\
08\end{array}$ & Mean & \\
\hline
\end{tabular}

Level of Zn Main effect of Zn

(kg/ha)

\begin{tabular}{ccccccccccccccccccc}
0 & 74.7 & $71.4 \mathrm{~b}$ & $68.5 \mathrm{~b}$ & $6.75 \mathrm{~b}$ & 6.67 & 6.60 & $0.63 \mathrm{c}$ & $0.60 \mathrm{c}$ & 0.59 & $26.8 \mathrm{~b}$ & $26.9 \mathrm{c}$ & $27.0 \mathrm{c}$ & 26.9 & $754 \mathrm{~b}$ & $732 \mathrm{~d}$ & $741 \mathrm{c}$ & 742.3 & - \\
1.5 & 77.0 & $71.9 \mathrm{~b}$ & $68.9 \mathrm{~b}$ & $7.06 \mathrm{~b}$ & 6.65 & 6.58 & $0.66 \mathrm{bc}$ & $0.63 \mathrm{bc}$ & 0.60 & $28.0 \mathrm{~b}$ & $28.9 \mathrm{c}$ & $28.3 \mathrm{c}$ & 28.4 & $801 \mathrm{~b}$ & $800 \mathrm{c}$ & $806 \mathrm{c}$ & 802.3 & 8.1 \\
3.0 & 77.4 & $73.9 \mathrm{a}$ & $71.2 \mathrm{a}$ & $7.55 \mathrm{a}$ & 6.78 & 6.66 & $0.71 \mathrm{a}$ & $0.68 \mathrm{a}$ & 0.61 & $35.5 \mathrm{a}$ & $37.4 \mathrm{a}$ & $35.3 \mathrm{a}$ & 36.1 & $977 \mathrm{a}$ & $1010 \mathrm{a}$ & $994 \mathrm{a}$ & 993.7 & 33.9 \\
4.5 & 77.3 & $73.7 \mathrm{a}$ & $71.0 \mathrm{a}$ & $7.45 \mathrm{a}$ & 6.72 & 6.64 & $0.69 \mathrm{ab}$ & $0.66 \mathrm{ab}$ & 0.61 & $33.4 \mathrm{a}$ & $34.1 \mathrm{~b}$ & $31.9 \mathrm{~b}$ & 33.5 & $923 \mathrm{a}$ & $930 \mathrm{~b}$ & $917 \mathrm{~b}$ & 923.3 & 24.4 \\
\hline $\begin{array}{l}\text { Probability } \\
<0.05\end{array}$ & NS & $*$ & $*$ & $*$ & NS & NS & $*$ & $*$ & NS & $*$ & $*$ & $*$ & - & $*$ & $*$ & $*$ & - & - \\
CV (\%) & 2.70 & 3.25 & 3.23 & 6.50 & 3.68 & 4.17 & 7.00 & 8.53 & 4.13 & 9.1 & 9.13 & 8.70 & - & 8.6 & 9.98 & 9.19 & - & - \\
\hline
\end{tabular}

Levels of B Main effect of B

(kg/ha)

\begin{tabular}{|c|c|c|c|c|c|c|c|c|c|c|c|c|c|c|c|c|c|c|}
\hline 0.0 & 75.1 & 71.9 & 69.4 & $6.84 \mathrm{~b}$ & 6.70 & 6.61 & $0.63 b$ & $0.60 \mathrm{~b}$ & $0.58 b$ & $26.5 \mathrm{c}$ & $26.4 \mathrm{c}$ & $26.2 b$ & 26.4 & 769c & $755 c$ & 753b & 759.0 & - \\
\hline 1.0 & 76.5 & 73.2 & 69.9 & 7.34a & 6.80 & 6.65 & 0.70a & $0.65 a$ & 0.60ab & 34.3a & $34.8 \mathrm{a}$ & $32.7 \mathrm{a}$ & 33.9 & 914ab & 926a & 912a & 917.3 & 20.9 \\
\hline 2.0 & 76.5 & 72.7 & 70.0 & 7.32a & 6.64 & 6.58 & $0.68 \mathrm{a}$ & $0.68 \mathrm{a}$ & $0.61 \mathrm{ab}$ & 33.1a & $34.9 a$ & 33.3a & 33.8 & $917 \mathrm{a}$ & 933a & 933a & 927.7 & 22.2 \\
\hline 3.0 & 75.4 & 73.1 & 70.4 & 7.31a & 6.68 & 6.63 & $0.68 a$ & $0.64 a$ & $0.62 \mathrm{a}$ & $29.9 b$ & $31.2 b$ & $30.4 a$ & 30.5 & $856 b$ & $857 \mathrm{~b}$ & 860b & 857.7 & 13.0 \\
\hline $\begin{array}{l}\text { Probability } \\
<0.05\end{array}$ & NS & NS & NS & * & NS & NS & * & * & * & * & * & * & - & * & * & * & - & - \\
\hline CV (\%) & 2.70 & 3.25 & 3.23 & 6.5 & 3.68 & 4.17 & 7.00 & 8.53 & 4.13 & 9.1 & 9.13 & 8.70 & & 8.6 & 9.98 & 9.19 & - & - \\
\hline
\end{tabular}

Figures in column having same letter(s) do not differ significantly at 5 percent level by DMRT 
Table 5. Response function of chilli to zinc and boron at SRC, Shivgonj, Bogra.

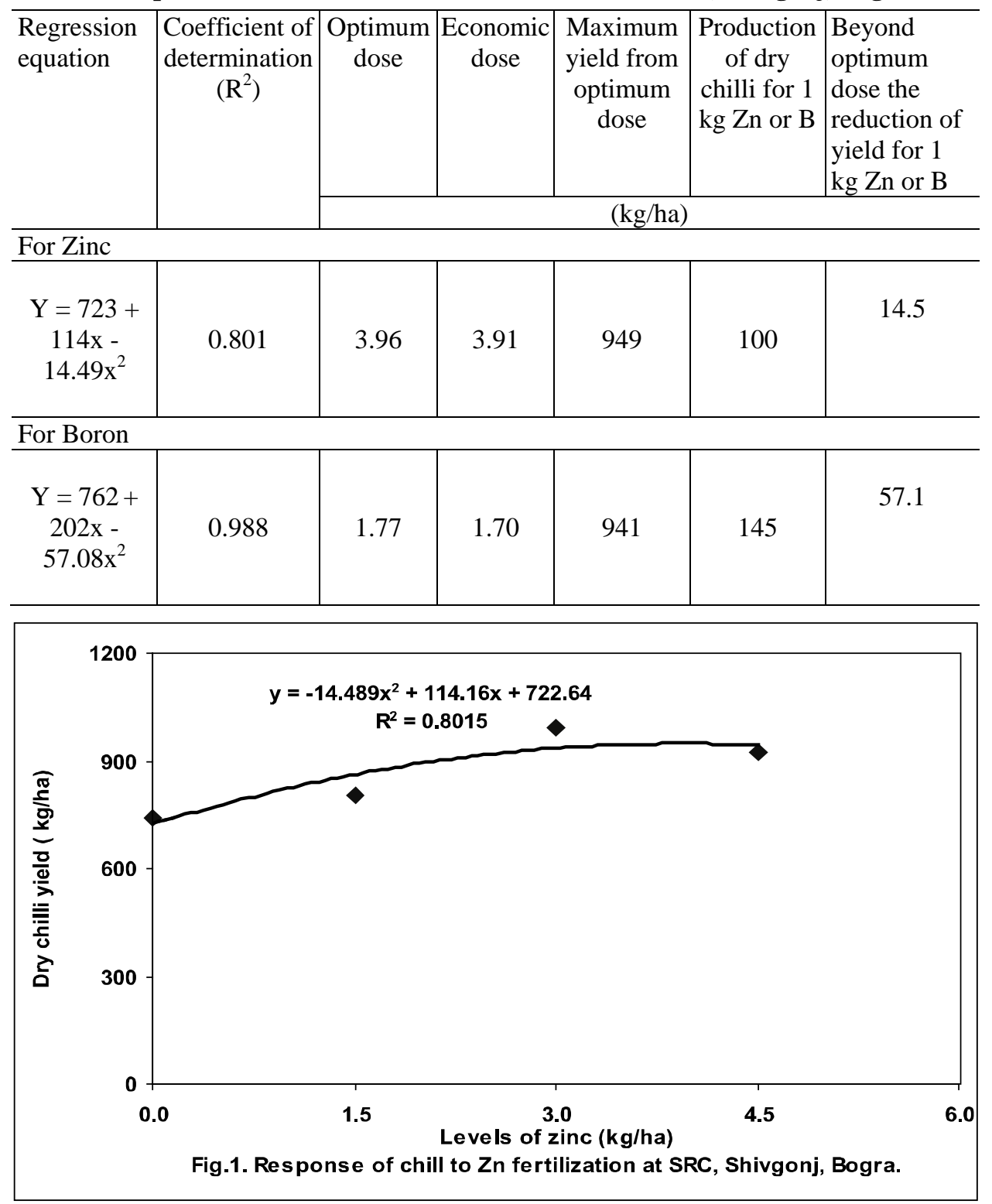




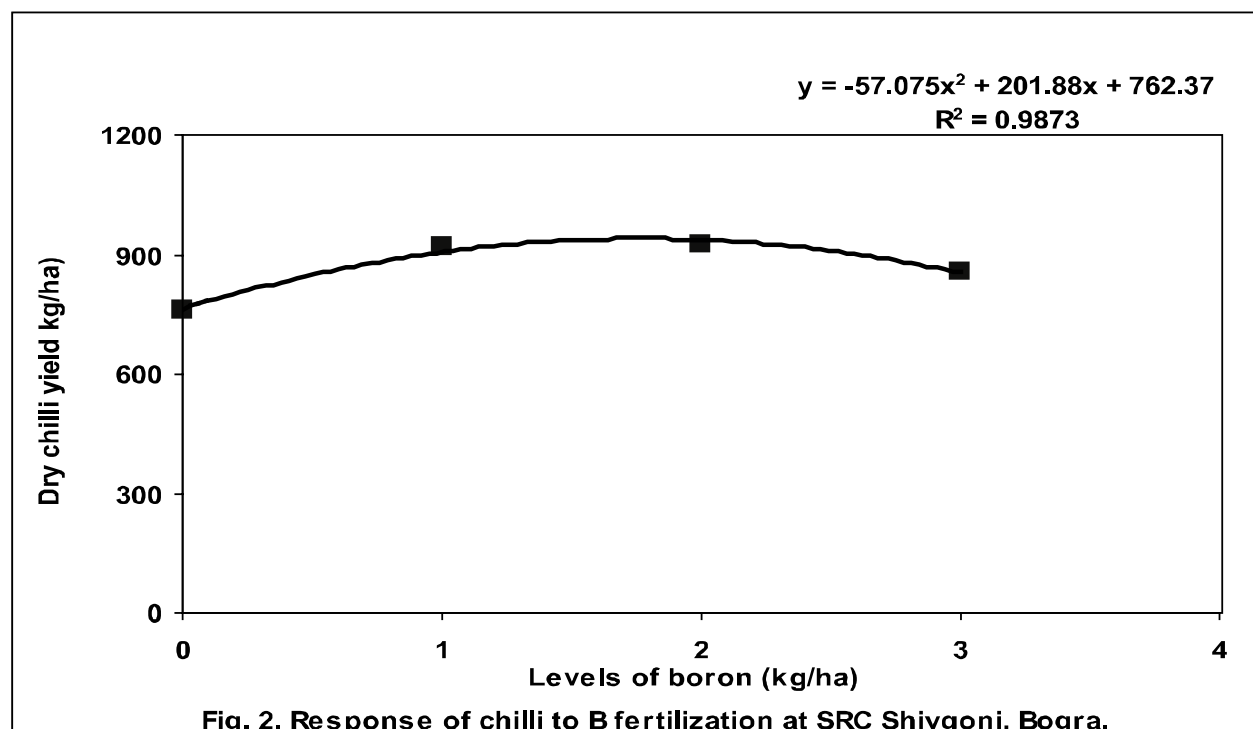

Similarly, different levels of boron showed quadratic relationship with yield (Fig. 2). The optimum dose of boron (1.77 kg/ha) was calculated from the quadratic equation (Table 5). Using the said optimum dose, the maximum yield $(941 \mathrm{~kg} / \mathrm{ha})$ could be expected for chilli at Bogra. The economic dose (1.70 $\mathrm{kg} / \mathrm{ha}$ ) of boron was worked out from the regression equation. The use efficiency showed that each $1 \mathrm{~kg}$ B could produce $145 \mathrm{~kg} / \mathrm{ha}$ of dry yield up to the optimum level. Beyond the said optimum dose, if $1 \mathrm{~kg} / \mathrm{ha}$ excess B is applied, then there is a risk of loosing $57.1 \mathrm{~kg} / \mathrm{ha}$ of yield.

\section{Conclusion}

Chilli was found responsive to both zinc and boron as revealed by consecutive three years’ study. Zinc @ 3.0 kg/ha and boron @ 1.0 kg/ha along with a blanket dose of $\mathrm{N}_{130} \mathrm{P}_{60} \mathrm{~K}_{80} \mathrm{~S}_{20} \mathrm{Mg}_{10} \mathrm{~kg} / \mathrm{ha}$ appeared as the best-suited combination. From the quadratic response function, the optimum-economic dose of boron and zinc were calculated to be 1.70 and $3.91 \mathrm{~kg} /$ ha, respectively. Thus a package of $\left(\mathrm{B}_{1.70}\right.$ $\mathrm{Zn}_{3.91} \mathrm{~kg} / \mathrm{ha}$ ) along with the said blanket dose may be recommended for the cultivation of chilli in Grey Terrace Soil under AEZ-25.

\section{References}

Ahmed, N. and M. I. Tanki. 1991. Haryana J. Hort. Sci. 20: 114-18. (Cited from Vegetable Crops. eds. Bose, T.K; M.G. Som and J. Kabir. 1993. Nays Prokash, 206, Bidhan Sarani, Calcutta 700006, India).

BBS. 2001. Year Book of Agricultural Statistics in Bangladesh. Bangladesh Bureau of Statistics, Ministry of Planning. Govt. of the Peoples Republic of Bangladesh, Dhaka. 
Benepal, P. S. 1967. Influence of micronutrients on growth and yield of potatoes. Ame. Pot. J. 44: 363-369.

Bose, U. S. and S. K. Tripathi. 1996. Effect of micronutrients on growth, yield and quality of tomato cv. Pusa Ruby in M. P. Cro. Res. 12: 61-64.

Fageria N. K., V. C. Baligar and R. B. Clark. 2002. Micronutrients in crop production. Adv. Agro. 77: 185-268.

Govindan, P. R. 1952. Influence of boron on yield and content of carbohydrates in tomato fruits. Curr. Sci. 21: 14-15.

Hatwar, G. P., S. U. Gondane, S. M. Urkude, and O. V. Gahukar. 2003. Effect of micronutrients on growth and yield of chilli. J. Soil Crops 13: 123-125.

Hedge, D. M. 1997. Nutrient requirements of solanceous vegetable crops. Extension Bulletin ASPAC, Food and Fertilizer Technology Center, No. 441, p. 9.

Karnataka.2009. Yield and quality of chilli ( $c v$. Bydagi dabbi) as influenced by secondary and micronutrients J. Agric. Sci. 22 (5) (1090-1092)

Mallic, M. F. R. and C. R. Muthukrishnan. 1979. Effect of micronutrients on tomato (Lycopersicon esculentum Mill). 1: Effect on growth and development. South, Ind. Hort. 27: 121-124.

Prabhakar, M. 1987. Effect of supplemental irrigation and nitrogen fertilization on growth, yield nitrogen uptake and water use of green chilli. Annals of Agricultural Research. 18(1): 34-39.

Rawat, P. S. and K. N. Mathpal. 1984. Effect of micronutrients on yield and sugar metabolism of some of the vegetables under Kumaon hill conditions. Sci. Cult. 50: 243-244.

Sharma, B. R., A. P. S. Chadha and H. K. Bajpai. 1996. Response of Chilli (Capsicum annum Linn.) to nitrogen and phosphorus levels under irrigated condition. Advances in Plant Sciences 2: 213-214.

Singh K. and B. K. Srivastava. 1988. Indian J. Hort. 45: (Cited from Vegetable Crops. eds. Bose, T. K; M.G. Som and J. Kabir. 1993. Nays Prokash, 206, Bidhan Sarani, Calcutta 700006, India).

Pillai, K. M. and K. K., Vadivelu. 1966. Effect of soil and foliar application of micronutrients on fruit number and yield of chillies under field conditions. South Indian Hort. 14 : 43-47.

Pillai, K. M. 1967. Effect of certain micronutrients combination on growth and yield of chilies under field conditions. Indian J. Agron. 12: 358 - 362. 